JURNALYOGA DAN KESEHATAN

JURUSAN YOGA KESEHATAN

FAKULTAS BRAHMA WIDYA

IHDN DENPASAR
Vol. 3 No. 2 September 2020

ISSN : 2621-0185 (Cetak)

ISSN : 2722-9440 (Online)

http://ejournal.ihdn.ac.id/index.php/jyk

\title{
Lontar Usada Rare: Memahami Kearifan Lokal Tradisional Bali dalam Mendiagnosa Gejala Penyakit Anak
}

\author{
Putu Eka Sura Adnyana \\ Institut Hindu Dharma Negeri Denpasar \\ email : ekasuraadnyana@gmail.com
}

Diterima tanggal 6 Agustus 2020, diseleksi tanggal 16 Agustus 2020, dan disetujui tanggal 27 Agustus 2020

\section{ABSTRACT}

Family problems become very crucial at this time due to the absence of family planning. Various reactions are shown by parents when the child is experiencing an illness. Not a few maidset parents who think that when a child is sick must be immediately taken to the doctor to get treatment and treatment through drugs. The disease diagnosis system accompanied by traditional treatments in Bali is known as Usada. One of them is usada rare papyrus is a papyrus that discusses the symptoms of disease in children and how to treat it in children. Lontar usada rare text describes the symptoms of illness experienced by a child, including upas disease, tiwang disease, sebaha disease, spells, scales, and other groups of diseases. Recognizing and understanding the symptoms of the disease based on the Usada Rare Lontar provides an early understanding of the symptoms of the disease in children through traditional Balinese diagnosis in a papyrus record.

Keywords: lontar usada rare; bali local wisdom; childhood disease

\section{ABSTRAK}

Masalah keluarga menjadi hal yang sangat krusial saat ini dikarenakan tidak adanya family planning. Beragam reaksi diperlihatkan oleh orang tua ketika sang anak mengalami kondisi sakit. Tidak sedikit maidset orang tua yang menganggap bahwa ketika anak sakit harus langsung dibawa ke dokter untuk mendapatkan penanganan dan perawatan melalui obat-obatan. Sistem pendiagnosaan penyakit yang disertai dengan cara pengobatan secara tradisional dibali dikenal dengan nama Usada. Salah satunya adalah lontar usada rare merupakan lontar yang membahas gejala penyakit pada anak dan cara mengobatinya pada anak. Teks Lontar usada rare menjelaskan gejala-gelaja penyakit yang dialami oleh seorang anak, diantaranya penyakit upas, penyakit tiwang, penyakit sebaha, penyakit jampi, penyakit sisik, dan kelompok penyakit lainnya. Mengenal dan memahami gejala-gejala penyakit tersebut berdasarkan lontar usada rare memberikan pemahaman secara dini terkait gejala penyakit pada anak melalui cara diagnosa tradisional Bali dalam sebuah catatan lontar.

Kata kunci: lontar usada rare; kearifan lokal bali; penyakit anak 


\section{PENDAHULUAN}

Keluarga merupakan unsur terkecil yang dewasa ini memegang peranan penting dalam kesehatan anak. Masalah keluarga menjadi hal yang sangat krusial saat ini dikarenakan tidak adanya family planning. Calon ayah dan calon ibu tidak memahami permasalahan yang dihadapi ketika sang anak sakit dikarenakan usia yang sangat belia untuk menikah, ngetrendnya disebut pamud "papa muda" dan mamud "mama muda. Beragam reaksi diperlihatkan oleh orang tua ketika sang anak mengalami kondisi sakit. Tidak sedikit maidset orang tua yang menganggap bahwa ketika anak sakit harus langsung dibawa ke dokter dan mendapatkan penanganan dan perawatan melalui obat-obatan. Perlu diketahui bahwa pemberian dan penanganan kondisi sakit dengan obat-obatan dapat berakibat fatal pada tumbuh kembang anak apabila tidak diberikan dengan tepat dan tanpa dosis yang sesuai.

Obat sesungguhnya bagaikan pisau bermata dua, maksudnya obat dapat bermanfaat bagi tubuh dan bisa pula menjadi racun bagi tubuh anak, sehingga hal ini perlu dipahami oleh orang tua. Peredaran obat diatur berdasarkan UU Kesehatan No.36 tahun 2009 dan Keputusan Menkes RI No. 661/Menkes/SK/VII/1994 menjadi Peraturan Menkes RI No. 7 Tahun 2012. UU Kesehatan No.36 tahun 2009 menjelaskan obat sebagai sebagai bahan atau panduan bahan termasuk produk biologi yang digunakan untuk mempengaruhi atau menyelidiki sistem fisiologi atau keadaan patologi dalam rangka penetapan diagnosis, pencegahan, penyembuhan, pemulihan, peningkatan kesehatan dan kontrasepsi. Selanjutnya obat digolongkan berdasarkan jenis menjadi 4 yaitu obat narkotika, obat keras, obat bebas terbatas dan obat bebas. Berdasarkan dalam pemasaran obat dikelompokkan menjadi tiga yaitu obat paten, obat generik bermerek dan obat generik (Tim Penyusun, 2019).

Menurut keputusan Menkes RI No. 661/Menkes/SK/VII/1994 yang menjadi Peraturan Menkes RI No. 7 Tahun 2012 mengatur tentang obat tradisional di Indonesia yang tidak memerlukan pembuktian ilmiah sampai dengan klinis, tetapi cukup dengan pembuktian empiris atau atau turun temurun. Obat tradisional dibagi menjadi 2 yaitu obat herbat terstandar $(\mathrm{OHT})$ dan Obat Fitofarmaka. Namun disamping obat yang diakui di Indonesia berdasarkan UU dan peraturan Kemenkes tersebut, disisi lain di pulau Bali terdapat sistem pendiagnosaan penyakit yang disertai dengan cara mengobati secara tradisional dikenal dengan nama Usada. Usada adalah ilmu pengobatan tradisional Bali memuat, filosofi sakit, nenger (diagnosa), dan pengobatan yang diwarisi dari generasi ke generasi. Pemahaman akan usada biasanya dituruntemurunkan dan tertuang diatas daun lontar. Lontar merupakan alas tulis dalam daun tal dengan menggunakan aksara Bali sebagai alat tulisnya sehingga dikenal dengan nama lontar usada (Jirnaya, 2011). 
Lontar usada dapat dimasukkan ke dalam pengetahuan karena di samping pengobatan juga memuat ilmu pengobatan, seperti Usada Buda Kacapi, Usada Rare, dan sebagainya (Nala, 2002: 18; Jirnaya, 2011:280-281). Eksistensi naskah lontar usada di Bali dianggap sangat penting dari zaman dahulu hingga sekarang ditahun 2020 ini. Indikasi dapat dibuktikan melalui jumlah naskah lontar usada di Bali diperkirakan beribu-ribu (Bija dan Ida Bagus Ketut Arisana, 2007:71). Naskah lontar usada tersebut umumnya tersimpan di masyarakat dan khususnya di lembaga formal, seperti Gedong Kirtya, Dinas Kebudayaan Provinsi Bali, UPT Lontar Universitas Udayana, Museum Bali, dan lain sebagainya. Apresiasi terhadap budaya tradisional yang diwariskan oleh para leluhur sudah semakin menipis. Pada kesempatan ini akan dikaji salah satu naskah lontar yang cukup penting bagi kita, yaitu lontar Usada Rare. Lontar usada rare adalah lontar yang membahas gejala penyakit dan cara mengobati pada anak. Membahas lontar usada rare sangat penting dilakukan dan bertujuan utk menggali pengetahuan kearifan lokal terutamanya memahami gejala penyakit pada anak yang terdapat dalam teks lontar usada rare. Tentunya dengan memahami jenis-jenis penyakit anak tersebut dapat bermanfaat bagi masyarakat luas dan terutamanya pengetahuan bagi orang tua "pamud dan mamud" dijaman modern ini yang mengadaptasi dari kearifan lokal tradisional Bali.

\section{PEMBAHASAN}

\subsection{Lontar Usada Rare}

Naskah lontar usada rare tersimpan di Unit Pelaksana Teknis (UPT) Lontar Universitas Udayana, terdapat juga di Gedong Kirtya Singaraja, dan Dinas Kebudayaan Provinsi Bali. Lontar usada rare memakai bahasa Jawa Kuna bercampur dengan bahasa Bali. Isi teks lontar usada rare menjelaskan jenis penyakit yang diderita pada anak dengan memiliki cirinya masingmasing. Setiap penyakit anak dengan ciri masing-masing tersebut berbeda pula cara pengobatan dan obatnya.Berikut jenis penyakit pada anak yang umum dirasakan anak sehingga perlu untuk diperhatikan oleh orang tua atau masyarakat, yang termuat dalam lontar usada rare disertai tatenger-nya "diagnose" dengan pengobatannya (Tim UPT, 2018).

\subsection{Tatĕngĕr dalam Lontar Usada Rare}

Tatěngĕr merupakan salah satu bagian terpenting dalam usadha. Secara leksikon tatěngĕr berasal dari leksikon tĕngĕr yang bermakna berciri, kedengaran, atau mengandung unsur yang khas (Sugiharta, 2020). Istilah tatěngěr diartikan sebagai usaha yang dilakukan untuk mengenali penyakit yang diderita berdasarkan ciri atau tandanya. Tatĕngĕr dan diagnosis dalam ilmu kedokteran modern hampir sama. Diagnosis adalah proses menentukan penyakit atau kondisi 
mana yang menjelaskan gejala dan tanda pasien. Dalam proses Tatĕngĕr ada beberapa aspek yang perlu diperhatikan, Sugiharta (2020) menyatakan aspek itu dikenal sebagai sapta ta, adapun sebagai berikut.

a. Tanya (Komunikasi) Seorang pengobat (balian) umumnya akan mengambil waktu sejenak sebelum menangani pasien. Kesempatan inilah yang digunakan untuk melakukan komunikasi baik dalam arti bercakap-cakap dengan pasien beserta keluarganya maupun dengan sesuhunan yang diiringnya

b. Tĕlěng/ Tĕlěb Sebagai tokoh pengobatan (balian) diyakini memiliki kekuatan penglihatan yang menyembuhkan (dharsan).

c. Tahĕn berarti menyentuh bagian tubuh pasien yang sakit maupun bagian-bagian lain yang berkaitan dengan suatu penyakit. Melalui penyentuhan yang hati-hati dengan pemberian penekanan tertentu sekaligus melakukan pemeriksaan (tureksa).

d. Tanda menentukan hidup mati pasien, umur penyakit, dan sebagainya. Melalui kemampuan membaca tanda yang baik seorang penyembuh tidak kelabakan dalam menentukan keputusan sehingga terhindar dari malu atau citra kurang professional.

e. Tangar adalah merupakan manifestasi dari kehati-hatian dan ketelitian yang harus dimiliki oleh seorang balian. Sekali lagi tangar tidak mungkin bisa diperoleh secara instan tanpa penggemblengan yang panjang.

f. Tenung berupa pembacaan aspek-aspek yang sekilas tidak ada hubungannya dengan penyakit namun dalam banyak kasus dapat membantu proses penyembuhan. Aspek-aspek yang dicermati oleh para balian ketika mendiagnosis suatu penyakit seperti hari kelahiran pasien, hari kambuhnya penyakit, keadaan pekarangan, gerak gerik, arah datangnya pasien, dan semacamnya.

g. Tamba (obat) merupakan puncak dari pemeriksaan-pemeriksaan sebelumnya yang dilihat sebagai sesuatu yang holistik. Kesalahan satu tahap saja dalam proses nĕngĕrin lara makan akan berakibat pada kesalahan memberikan obat (Sugiharta, 2020).

Berdasarkan penjelasan Sugiarta (2020) dapat dipahami bahwa banyak aspek yang perlu diperhatikan dalam proses tatenger "diagnosa" dalam ilmu pengobatan tradisional Bali, sedangkan melalui teks Lontar Usadha Rare, tatenger "diagnose" dapat dilakukan melalui membaca teks yang beraksara bali dalam daun lontar tersebut, sehingga dapat dijelaskan diagnosa dan jenis penyakit yang diderita pada anak dan dipahami gejala-gejala penyakitnya. Lontar usadha rare mendeskripsikan dengan baik, sehingga membantu proses dari tatenger atau negerin yang dilakukan seorang pengobat (tabib) atau masyarakat. 


\subsection{Gejala dan Penyakit Anak dalam Lontar Usada Rare}

Lontar usada rare setelah dibaca dan dipahami (direduksi, dan diverifikasi datanya) maka dapat dikelompokkan jenis-jenis penyakit anak yang dinamai pada lontar usada rare diantaranya penyakit upas, penyakit tiwang, penyakit sebaha, penyakit jampi, penyakit sisik, dan kelompok penyakit lainnya (UPT, 2018). Penyakit-penyakit ini sering diderita oleh anak, sehingga sangat baik untuk dipahami ciri-ciri gejalanya, adapun gejala dan penyakitnya, sebagai berikut.

1. Penyakit upas

Upas merupakan jenis penyakit yang dominan menyerang kekebalan tubuh. Upas atau yang dikenal dengan nama Dermatitis merupakan jenis penyakit yang menyerang kulit manusia. Kulit tidak hanya berfungsi sebagai lapisan pelindung, tetapi merupakan suatu organ kompleks, yang merupakan organ terluas di tubuh. Dermatitis adalah peradangan kulit (epidermis dan dermis) sebagai respon terhadap pengaruh faktor eksogen dan endogen, menimbulkan kelainan klinis berupa efloresensi polimorfik dan keluhan gatal. Lesi dermatitis terasa gatal, bengkak seperti plak basah, kadang mengandung vesikel dan bula (Robbins, 2018). Masyarakat Bali memiliki cara tersendiri untuk menyembuhkan upas/dermatitis. Dalam lontar usada rare ditemukan gejala penyakit upas yang dialami oleh anak, adapun penyakit upas tersebut sebagai berikut

a) Inilah tanda-tanda anak terkena penyakit upas. Jika anak merasa lemah tanpa tenaga, dinamakan terserang penyakit upas tawun;

b) Jika ada tampak garis-garis merah pada kuku si anak itu dinamakan terserang penyakit upas hyang;

c) Jika pada kuku si anak tampak gumpalan darah, dinamakan terkena penyakit upas warangan;

d) Jika mata si anak terlihat tampak kuning agak kemerahan, dinamakan terserang penyakit upas dewe;

e) Jika anak mengalami mual-mual atau muntah-muntah, disertai dengan enek, sesak nafas, penyakit itu dinamakan penyakit upas uyak

f) jika anak merasa mual saja dan enek, itu dinamakan terserang penyakit upasilali.

2. Penyakit tiwang

Tiwang merupakan kondisi penurunan kesadaran yang berat pada fungsi serebral. Tiwang atau yang disebut sebagai koma merupakan keadaan tidak sadar yang dalam, yang tidak dapat dibangunkan akibat disfungsi ARAS (ascending reticular activating system) di batang otak atau kedua hemisfer serebri (Robbins, 2018). Penyakit tiwang ini dapat 
menyebabkan seseorang tidak merespon/bereaksi ketika diberikan rangsangan. Faktor penyebab penyakit tiwang adalah adanya infeksi atau inflamasi, struktural, dan metabolik, nutrisi, atau toksik. Adapun gejala penyakit tiwang dalam lontar usada rare, sebagai berikut.

Jika tangan, kaki, dan tubuh si pasien kejang-kejang, matanya agak memerah, dinamakan terserang tiwang penyu. Jika mulut si anak menganga atau tertutup rapat, bulu tubuhnya berdiri, rambutnya kaku, dinamakan terserang penyakit tiwang sona. Jika mata si anak tampak kering dan berkedip, dinamakan terserang penyakit tiwang kapi. Jika anak berbengah-bengah, dinamakan terserang penyakit tiwang jaran.Ada lagi tanda-tanda penyakit tiwang pada anak, yaitu jika tangan dan anak kejang dan kaku, dinamakan terserang penyakit tiwang gurita. Jika tubuh anak terasa berat, dinamakan terserang penyakit tiwang kebo. Jika anak menangis kesakitan siang-malam, tubuhnya kejang-kejang, dinamakan terserang penyakit tiwang kupuкири. Jika anak kadangkala tampak pucat, mukanya tampak agak memerah, dinamakan terserang penyakit katepuk tegah dewa. Apabila anak menderita sakit perut, terasa melilit, dinamakan penyakit tiwang gurita. Jika anak menderita muntah-muntah, dinamakan terserang penyakit tiwang belabor. Jika perutnya mual-mual, bergerak naik mendesak hingga ke hulu hati, itu dinamakan penyakit tiwang balukung. Jika tubuh anak kaku, tangannya menggenggam, lidahnya terjepit, dinamakan terserang penyakit tiwang dengen. Jika tubuh anak terasa seperti ditusuk, mual-mual dan terasa henek di hulu hati, dinamakan terserang penyakit tiwang temen. Jika alis anak berkedutan, dinamakan terserang penyakit tiwang bojog. Jika punggung pasien melengkung, tidak bisa membalikkan badan, dinamakan terserang penyakit tiwang bangke. Jika kaki anak lemas, tidak bisa berkata, dinamakan terserang penyakit tiwang bantang Jika hulu hati anak terasa sakit, melilit-lilit di pusar, gelisah, disebut terserang penyakit tiwang lumba-lumba. Jika pusar anak terasa sakit melilit, dinamakan terserang penyakit tiwang wedus. Jika perut anak terasa melilit, dinamakan terserang penyakit tiwang rare. Jika perut anak terasa bergerak naik membatu, dinamakan terserang penyakit tiwang lesung. Jika hulu hati anak terasa kaku, sikunya menyingguknyingguk, dinamakan terserang penyakit tiwang tundik. Jika hulu hati anak terasa seperti ditusuk dinamakan terserang penyakit tiwang mong, dan jika disertai rasa menusuk ke dalam, dinamakan terserang penyakit tiwang rangsek. Jika tubuh anak terasa gerah, dinamakan terserang penyakit tiwang bangke, matanya melotot. Jika tangan anak kaku, dinamakan terserang penyakit tiwang gurita.

Jika tubuh anak terasa berat, dinamakan terserang penyakit tiwang kebo. Jika anak membelit-belit, dinamakan terserang penyakit tiwang be julit. Jika tangan anak kuat bergerakgerak, dinamakan terserang penyakit tiwang gurita. Jika mulut anak kadangkala menganga 
atau kadangkala tertutup, dinamakan terserang penyakit tiwang mang. Jika tangan dan kaki anak kaku, serta berkedut-kedut, dinamakan terserang penyakit tiwang penyu. Jika tubuh anak tampak kehitaman, dinamakan terserang penyakit tiwang gowak. Jika mulut anak menganga dan kadangkala tertutup, dinamakan terserang penyakit tiwang asu. Jika alis anak berkedut, dinamakan terserang penyakit tiwang bojog. Jika anak merasa kesakitan dan gelisah, dinamakan terserang penyakit tiwang utara. Jika anak merasa sakit pada bagian dalam, perutnya terasa berkedut-kedut, dinamakan terserang penyakit tiwang ngalud. Jika anak merasa sakit seperti ditusuk-tusuk hingga ke punggung, setiap mau bernafas, dinamakan terserang penyakit tiwang pamali. Jika anak merasa kesakitan pada malam hari seperti ditusuk-tusuk, dinamakan terserang penyakit tiwang mong. Jika anak merasa sakit seperti dicubit-cubit, dinamakan terserang penyakit tiwang asu. Jika anak merasa mengirai-ngirai, dinamakan terserang penyakit tiwang babi. Jika perut anak terasa kaku hingga ke hulu hatinya, dinamakan terserang penyakit Tiwang sula walikat. Jika anak merasa sakit perut dan kembung, dinamakan terserang penyakit tiwang buntek. Jika anak merasa sakit perut melilit, seperti ditusuk-tusuk, dinamakan terserang penyakit tiwang nanipi. Jika anak merasa sakit di bagian lambung, rasa sakitnya datang-pergi, dinamakan penyakit tiwang angina. Jika tubuh anak kaku, dagunya kaku, dinamakan penyakit tiwang bantang.

Jika anak tertidur pulas terus menerus, dinamakan terserang penyakit tiwang bangke. Jika anak merasa sakitnya seperti menjalar ke perut, dinamakan terserang penyakit tiwang gurita. Jika tubuh anak terasa gerah dan perutnya kembung agak kaku, dinamakan terserang penyakit tiwang babahi. Jika anak merasa pusing-pusing, dinamakan terserang penyakit tiwang guwak. Jika anak merasa sakit perut dan batuk, dinamakan terserang penyakit tiwang bebek. Jika tubuh anak kaku, dinamakan terserang penyakit tiwang lojor. Jika tubuh anak panas dan matanya melotot, dinamakan terserang penyakit tiwang bangke. Jika tangan dan kaki anak kaku, seperti menggenggam sesuatu, dinamakan terserang penyakit tiwang gurita. Jika mulut anak menganga, dinamakan terserang penyakit tiwang mang. Jika anak muntah-muntah, dinamakan terserang penyakit tiwang belabor. Jika hulu hati anak berdetak-detak, dinamakan terserang penyakit tiwang gagedul. Jika anak kurang bertenaga, bagaikan orang tidur, dinamakan penyakit tiwang bayu. Jika anak sakit suka menggelengkan kepala, dinamakan penyakit tiwang powak. Jika anak perut kembung, sering kaku, melilit-lilit, dinamakan penyakit tiwang bruwang. Jika anak, mengalami meraba-raba, tangan dan kakinya kaku dinamakan penyakit tiwang gugung. Jika tulang punggung anak melengkung, dinamakan penyakit tiwang dopang. Jika anak terasa sakit seperti ditusuk-tusuk, dinamakan penyakit tiwang gode. Jika anak meriang, tangan dan kaki terasa kaku, dinamakan penyakit tiwang 
beruang. Jika tubuh anak terasa gatal-gatal, dinamakan penyakit tiwang gatel. Jika tangan anak menggapai-gapai, dinamakan penyakit tiwang nyalian. Jika tangan anak terbuka, kepalanya menggeleng-geleng, menengadah, dinamakan terkena penyakit tiwang sikep. Jika tubuh anak tampak kehitaman, dinamakan sakit tiwang lenga. Jika anak suka menangis setiap malam, tidak jelas apa yang dimintanya, dinamakan terserang penyakit tiwang tumreretan. Jika anak sering terkejut, ketakutan, dinamakan terserang penyakit tiwang kupu-kupu.

3. Penyakit sebaha

Sebaha atau edema merupakan penumpukan cairan secara abnormal di ruang interselular tubuh (Dorland, 2013). Edema menandakan adanya kebocoran cairan tubuh melalui dinding pembuluh darah. Cairan ini kemudian menumpuk pada jaringan di sekitarnya dan menyebabkan pembengkakan. Adanya penumpukan cairan disebabkan oleh beberapa faktor yaitu peningkatan tekanan hidrostatik, penurunan tekanan onkotik plasma, obstruksi saluran limfe, peningkatan permeabilitas kapiler (Robbins, 2018). Edema bisa terjadi diseluruh bagian tubuh seperti tangan, kaki, dan lain sebagaiannya. Adapun gejala penyakit sebaha dalam lontar usadha sebagai berikut.

a) Apabila tubuh anak terasa gerah setiap sore hari, nafasnya kencang, nafas yang keluar dari hidungnya terasa panas, pertanda si pasien menderita panas. Dan jika nafasnya mengendor, jari-jari tangan dan kakinya dingin setiap sore, nafas yang keluar dari mulut terasa panas, pertanda anak menderita penyakit sebaha gantung.

b) Jika aliran tenaga panas, tangan dan kakinya dingin, pertanda anak menderita sebaha jampi.

c) jika bibir anak pecah-pecah, nafas di hidung terasa dingin dan agak tertahan, jari-jari kakinya dingin, sekujur tubuhnya gerah, pertanda si pasien menderita sebaha jampi.

d) Jika anak bibirnya kering, dan mual-mual, nafas di hidung terasa panas, gerah setiap menjelang sore, tangan dan kakinya dingin, pertanda si pasien menderita sebaha jampi.

e) apabila jari-jari kaki si anak panas, nafas di hidung terasa dingin, pertanda si pasien menderita asrep kapendem.

f) Jika nafas di hidung anak terasa panas, jari-jari kakinya panas, kukunya tampak kemerahan, pertanda si pasien menderita panas terus.

g) Jika jari-jari kakinya dingin, bibirnya terbuka-tertutup, pertanda anak menderita srep terus dan si bayi tidak mau makan dinamakan menderita sebaha nyuh,

4. Penyakit Jampi (sariawan) atau biasa disebut dengan stomatitis.

Stomatitis didefinisikan sebagai inflamasi (peradangan) generalisata pada mukosa mulut (Dorland, 2013). Penyakit ini dapat disebabkan oleh beberapa faktor yang melibatkan kondisi 
sistemik, lokal, genetik trauma, stres, hormonal, defisiensi faktor hematologis seperti kekurangan zat besi, vitamin B12, asam folat, dan akibat dari adanya imunologi yang tidak normal. Penyakit jampi/stomatitis ini bersifat self limited atau dapat dikatakan mampu sembuh dengan sendirinya, namun tetap saja kehadirannya sangat menggangu pada aktivitas rongga mulut seperti pengunyahaan, berbicara, dan kebersihan rongga mulut pun terganggu. Meskipun bersifat self limited penyakit ini dapat aktif/reaktivasi bila daya tahan tubuh rendah (Robbins, 2018). Adapun gejala penyakit jampi dalam lontar usada rare, sebagai berikut.

a) Jika anak menderita sakit jampi, terasa sakit di pinggang, di bibir, dan di lidah, serta merasa sesak

b) Jika anak menderita jampi dan perut kembung, dinamakan penyakit jampi agung, dan terasa kaku di bagian hulu hati, agak perih, batuk agak kering tidak putus-putusnya

c) Jika anak menderita mual-mual dan mengeluarkan buih dinamakan penyakit jampi mual

5. Penyakit Siksik atau Helmintiasis

Siksik atau Helmintiasis (kecacingan) menurut WHO adalah infestasi satu atau lebih cacing parasit usus yang terdiri dari golongan nematoda usus (WHO, 2013). Cacing umumnya tidak menyebabkan penyakit berat sehingga seringkali diabaikan walaupun sesungguhnya memberikan gangguan kesehatan. Tetapi dalam keadaan infeksi berat atau keadaan yang luar biasa, kecacingan cenderung memberikan analisa keliru kearah penyakit lain dan tidak jarang dapat berakibat fatal. Diantara nematoda usus ada sejumlah spesies yang penularannya melalui tanah atau biasa disebut dengan cacing jenis STH yaitu Ascaris lumbricoides, Necator americanus, Trichuris trichiura dan Ancylostoma duodenale (WHO, 2013). Adapun gejala penyakit siksik dalam lontar usada rare, sebagai berikut.

a) Jika putih mata anak tampak kebiruan, bulu matanya kusut, pangkal lehernya terasa bagaikan dijerat, anak itu dinamakan terkena serangan penyakit siksik.

b) Jika anak baru saja tidur, tiba-tiba bangun menangis tiada jelas apa yang diminta, setiap hari tubuhnya gerah, tetapi kuat makan, anak itu dinamakan terserang penyakit siksik.

c) Jika ada anak kurus kerempeng, kuat makan, pangkal lehernya terasa bagaikan dijerat, anak itu dinamakan terserang penyakit siksik

d) Jika ada anak kuat makan, berkeringat bercucuran, suka menangis malam hari, putih matanya tampak kebiruan, bulu matanya kusut, dinamakan terserang penyakit siksik lengis. 


\section{Penyakit lainnya}

Disamping beberapa penyakit diantaranya penyakit upas, penyakit tiwang, penyakit sebaha, penyakit jampi, dan penyakit sisik, ditemukan pula ada gejala penyakit lainnya yang dijelaskan dalam lontar usada rare, sebagai berikut.

a) Penyakit puruh ulad-alid, yakni dengan gejala mengeluarkan air dari hidung anak secara terus menerus.

b) penyakit tuju dengan gejala tangan, kaki, bibir, hidung, alis berkedut-kedut pada anak, tidak bisa berjalan, merasa seperti ditusuk-tusuk.

c) Jika anak tubuhnya sakit merinding atau bengkak, sakit melilit-lilit, dinamakan terkena penyakit moro.

d) Jika anak keluar darah dari hidung, dinamakan penyakit mokan tumisyan.

e) jika pantat anak mengeluarkan darah, dinamakan penyakit tuju moro.

f) Jika anak menderita gatal-gatal dan korengan, dinamakan barah gatel ring jro.

g) Jika anak sulit berak, kepalanya terasa panas, tubuhnya meriang, setiap bergerak menangis, lehernya tampak lemas, bayi itu terkena penyakit belahan.

h) Jika anak menangis gelisah, tangannya bagaikan menggenggam sesuatu, tubuhnya berkeringat, pertanda hulu hatinya sakit.

i) Jika tangis anak menjerit-jerit, tubuhnya berkeringat, pertanda anak itu terserang penyakit pamalinan.

j) Jika kondisi tubuh anak gerah, kotorannya kering, dan selalu rewel, tubuhnya tampak kemerahan, kuning, putih, hitam, perutnya kembung, sekejap riang, seketika lemas, pertanda anak itu terserang penyakit sarab ring jro.

k) Jika penyakit sarab itu keluar, maka tubuh anak akan tampak merah seperti mengandung darah, panas menggigil, pertanda anak terserang penyakit barah ring jro.

1) Jika kuku si anak tampak berwarna kuning, dinamakan terserang penyakit upas krikan gangsa.

m) Jika anak menderita sakit perut, henek di hulu hati, dan mencret, dinamakan terserang penyakit garabab.

\section{PENUTUP}

Berdasarkan penjelasan tersebut, dapat dipahami bahwa lontar usadha rare sesungguhnya merupakan salah satu cara untuk memahami kearifan lokal tradisional bali terutamanya dalam mendiagnosa gejala penyakit anak melalui sebuah peninggalan yang adi luhung. Lontar usada rare menjelaskan gejala-gelaja penyakit yang dialami oleh seorang anak, 
diantaranya penyakit upas, penyakit tiwang, penyakit sebaha, penyakit jampi, penyakit sisik, dan kelompok penyakit lainnya. Mengenal dan memahami gejala-gejala penyakit tersebut berdasarkan lontar usada rare memberikan pemahaman dalam mengenal penyakit anak melalui cara diagnosa tradisional Bali dalam sebuah catatan lontar. Dengan memahami gejala penyakit pada anak maka akan memahami cara mengobatinya dengan kearifan tradisional Bali.

Tentu saran bagi masyarakat, instansi kesehatan dan terkhususnya mahasiswa kesehatan harus memahami isi dari lontar usada rare dan gejala penyakit anak yang terdapat dalam lontar usada rare agar mampu mengkombinasikan catatan leluhur dengan dunia pengobatan dan kedokteran masa kini. Catatan-catatan dalam lontar usada terutamanya lontar usada rare masih sangat relevan dengan gejala-gejala penyakit yang dirasakan anak, sehingga sangat perlu dilakukan penelitian-penelitian lebih lanjut berkaitan dengan lontar usada melalui pendekatan pengobatan masa kini, dengan mengintegrasikan budaya kedalam ranah pengobatan dan kesehatan (Utami 2019).

\section{DAFTAR PUSTAKA}

Bija, I Made dan Ida Bagus Ketut Arinasa. 2007. "Pengobatan Tradisional Menurut Lontar Usada Bali." Prosiding. Seminar Konservasi Tumbuhan Usada Bali dan Peranannya dalam Mendukung Ekowisata. Jakarta: Indonesian Institute of Science (LIPI).

Dorland. 2013. Kamus Saku Kedokteran Edisi Ke-29. Singapura: Elsevier

Jirnaya, I Ketut. 2011. Usada Budha Kacapi: Teks Sastra Pengobatan Tradisional Masyarakat Bali. Desertasi. Denpasar: Program Pascasarjana Universitas Udayana.

Jirnaya, I Ketut. 2011. Lontar Usada Buduh: Sebuah Penanganan dan Pengobatan Tradisional Sakit Gila Berbasis Kearifan Lokal Bali. Denpasar: Universitas Udayana.

Nala, Ngurah. 2002. Usada Bali. Denpasar: PT Upada Sastra.

Robbins. 2018. Buku Ajar Patologi Dasar Edisi ke-10. Singapore: Elsevier

Sudaryanto. 2015. Metode dan Aneka Teknik Analisis Bahasa: Pengantar Penelitian Wahana Kebudayaan secara Linguistik. Yogyakarta: Sanata Dharma University Press.

Sugiharta ,I Putu Suweka Oka. 2020. Tatěngĕr : Diagnosa dalam Usadha Bali. Jurnal Yoga dan Kesehatan IHDN Denpasar. Denpasar: IHDN

Tim UPT. 2018. Koleksi Lontar Usadha Rare. Denpasar: Universitas Udayana Tim Penyusun. 2019. Basic Medical Sciences. Denpasar: FKIK Unwar Utami, Tri Niswati \& Reni Agustina Harahap. 2019. Sosioantropologi Kesehatan Integrasi Budaya dan Kesehatan. Jakarta: Prenadamedia Group.

WHO. 2004. Prevention and control of schistosomiasis and soil transmitted helminthiasis. Geneva: World Health Organization. 